\title{
Hvor moderne er dannelsen?
}

Birgit Eriksson: Moderne dannelse. Goethes Wilhelm Meister og dannelsesromanens aktualitet. Aarhus: Aarhus Universitetsforlag, 2013, 308 sider.

Det kan virke lidt bagvendt, at Birgit Eriksson kalder sin bog Moderne dannelse og i undertitlen taler om "dannelsesromanens aktualitet", for de to aspekter fylder mindst i det, der frem for alt er en gennemgang og analyse af Goethes roman Wilhelm Meisters Lehrjahre fra 1795/96. Men læser man "moderne" i udvidet betydning, som dækkende hele den borgerlige epoke, virker det mindre bagvendt, og selvfølgelig er "dannelse" udgangspunktet for det hele. Eftersom Goethes roman stadig er en af de mest autoritative formuleringer af en dannelsesproces, er der god mening i at fordybe sig i den, skønt - eller netop - fordi dannelsen i disse tider har trange kår. Der tales nok mere om den end for et par årtier siden, men de kræfter, som umuliggør den, er langt de stærkeste. Neoliberalismen har frisat en narcissisme, som ofte dyrkes også af dem, der fører dannelse i munden, og som derfor trækker begrebet længere og længere over i retning af tilpasning: til markedet, til "globaliseringen", til konkurrencen, den civile udgave af krigen - eller såmænd til krigen selv.

Man behøver blot at se på de debatter, der føres om skole og uddannelse: Borte har taget alle positive argumenter om personlig udvikling og et rigere liv; tilbage er alle de negative om tab af konkurrenceevne og markedsandele. Borte har taget håbet, tilbage står truslerne. Det skal nok virke inspirerende på den unge generation! Margaret Thatchers parole om, at der ikke findes samfund, men kun den enkelte og staten, var en undsigelse af alt, hvad der hedder dannelse og personlig myndighed; tilbage var - og er - forbrugeren på den ene side og den allestedsnærværende overvågning og disciplinering på den anden. Derfor er jeg nok skeptisk over for Birgit Erikssons formuleringer til sidst - f.eks. s. 291 - om, at "kravet om individuel myndighed [er] blevet både udbredt og radikaliseret.” Ja, måske i den såkaldte diskurs, men ikke nødvendigvis i det levede liv, hvor standardiseringen breder sig mere og mere. Men det er så her, diskussionen kan begynde.

Den individuelle frihed er måske den største kimære i vor tid: Hvad nu om prisen for den totale ytringsfrihed - for at tage et fortærsket eksempel - er, at det er ligegyldigt, hvad der bliver sagt? Eller om kunstens autonomi betyder, at resten af verden enten bliver ligeglad med kunsten eller højst ser den som et forbrugsgode? Friedrich Schiller, som på den ene side gerne ville hævde kunstens frihed, men på den anden side var bevidst om netop denne risiko, skrev derfor - samtidig med Goethes Meister-roman - om "menneskets æstetiske opdragelse"; han kunne også have skrevet dannelse.

"Man kan ikke være dannet for sig selv," sagde Villy Sørensen engang i et interview og pegede dermed på, at dannelse er et socialt ideal, ja i det hele taget et ideal om socialitet. 
Dannelse er, kunne man også sige, forudsætningen for civilsamfund - og vice versa. Og civilsamfundet vil altid stå i et spændingsforhold til både individet og staten (eller de storforetagender, som er trådt i dens sted), fordi ingen af dem interesserer sig for meningen med tingene, eller livet for den sags skyld, men alene for magten, den indbildte eller den faktiske. På vej hjem fra Italien i 1788 noterede Goethe om sin Wilhelm, som han dengang så ud, dvs. i den første romanversion, at han "fører en ubetinget eksistens", men "netop fordi han handler frit og uden hensyn" bliver mere og mere afhængig og ufri.

Kort sagt: Der er god grund til at beskæftige sig med Goethes roman og til at glæde sig over, at Birgit Eriksson har gjort det så grundigt. Hun trækker temaer og motiver frem til nærmere beskuelse og påviser brudlinjer og tvetydigheder i bogen. Det gjorde i øvrigt allerede dens første og måske til dato klogeste læsere som Schiller eller Friedrich Schlegel, men det gør ikke arbejdet mindre nyttigt. Selve ordet dannelsesroman stammer i øvrigt ikke fra Goethe, men fra en gymnasierektor Karl Morgenstern, som brugte det i en artikel $i$ et skoleprogram fra 1820, og det blev først efterhånden til en genrebetegnelse og i det 20. århundrede især udviklet af Wilhelm Dilthey. Hvor præcis en betegnelse det er, kan diskuteres; man har jo også begrebet udviklingsroman, og der er lavet subtile analyser af, hvorfor den tyske (og i parentes bemærket den danske) variant er blevet kaldt en dannelsesroman - enten, som dens fortalere siger, fordi der er mere indre udvikling i den end i den engelsk-franske udviklingsroman fra Fielding til Balzac, eller - mere kritisk - fordi de tyske og danske ure gik lidt bagefter den vesteuropæiske normaltid (som altså forudsættes at være normaltiden), og de tyske og danske romaner derfor ikke indoptog så meget samfund i sig, men blev mere navlebeskuende. Ganske vist sagde Friedrich Schlegel om Goethes roman, at man vanskeligt kunne forestille sig en mere levende skildring af samtiden, og Morgenstern så netop dette som et væsentligt træk ved genren; men de var jo også selv tyskere. Både på tysk og dansk har ordet dannelse det særlige fortrin, at det betyder både processen og resultatet, hvad der ikke gælder ordet udvikling.

Birgit Eriksson diskuterer i første del af sin bog dannelsesromanen som genre, herunder også, hvorledes den ikke alene sigter på at vise en dannelsesproces, men også at bidrage til læserens egen dannelse - Goethe sagde i sin alderdom, at han håbede, at hans læsere også ville opleve hans værker, hvormed han mente at nyttiggøre dem for sig selv; jeg anførte da også i sin tid i min disputats, at jeg selv var en del af romanens virkningshistorie, og at der derfor ikke fandtes noget arkimedisk punkt, hvorudfra den kunne betragtes.

Dette tages op i Anden del af Birgit Erikssons bog, som ganske vist har overskriften "Wilhelm Meisters Læreår", men som inden omtalen af selve romanen drøfter modtagelsen af den og dens videre virkningshistorie, også i forskningen. Man kunne godt have ønsket, at selve værket ikke blev pakket så meget ind, som tilfældet er, men at rækkefølgen havde været omvendt: først analyser af prægnante tekststeder eller af særlige motiver - og så derefter perspektiveringen. Som det er nu, kan analysen af romanen komme til at virke som en bekræftelse af det, der er blevet slået fast på et metaniveau, og det er lidt synd, fordi romananalysen rummer adskillige gode iagttagelser, om end ingen ny fortolkning - men hvorfor også, når der nu er tale om en dannelsesroman. Men det er nyttigt at få repeteret f.eks. brevvekslingen mellem Schiller og Goethe, som så anskueligt viser forskellen mellem dem: Medens Schiller ønsker en tydeliggørelse af romanens idé, 
benægter Goethe ret beset, at den har en sådan, og Schiller, som ellers havde fået lov at læse med undervejs, får ikke de to sidste "bøger" at se, inden de går i trykken. Goethe påberåber sig et "realistisk tic", som gør det umuligt for ham at opfylde Schillers ønsker; og just derfor er det en roman, han skriver - den relativt nye, åbne prosagenre, som i princippet har plads til alt, også til det, der løber ud ad tangenten.

Det skyldes, at alt er i bevægelse, både hovedpersonen og hans omgivelser. Wilhelm Meister begynder med at ville skabe et "nationalteater", hvilket også skal forstås som skabelsen af en moderne offentlighed, og han skal undervejs lære, at han skal noget andet, eller at teatret ikke er vejen til det, han tænker sig. Måske skal han i det hele taget lære at tænke sig noget i stedet for blot at drømme eller følge sine indskydelser. Han skal finde ind i verden, og den skal finde ind i ham, men i og med, at han kommer med sit, bliver også verden en smule anderledes end før (se f.eks. s. 122: Goethe lader "både jeg og verden forandre sig.")

Det ses mest tydeligt i det "tårnselskab", som diskret har ledet Wilhelms skridt, og som i takt med hans voksende myndighed opløser sig selv, tager afsked med sin mystik som "ungdommeligt hokuspokus" og i stedet bliver til en slags multinationalt forsikringsselskab, som kan afbøde følgerne af større omvæltninger (romanen er skrevet efter den franske revolution, men foregår inden denne). På det romanindividuelle plan viser det sig i, at det ret beset først er den borgerlige Wilhelm Meisters tilstedeværelse, som gør det muligt for romanens (lav-)adelige personer at finde sammen i de rigtige parforhold; først kompliceres det hele, så opløses forviklingerne. Jeg er ikke helt enig med Birgit Eriksson i her at se "den gensidigt underminerende op- og nedskrivning af perspektiverne" (s. 235); jeg tror, at det skal læses mere positivt (men det ligger nok også i "op-"), som en slags "historisk kompromis" og alternativ til revolutioner.

Men Wilhelm er ikke lærenem, og det er måske romanens hovedpointe. Hans dannelse får sin substans af hans træghed eller af det, som Goethe i den ovenfor citerede optegnelse kaldte hans "ubetingede eksistens". Det er det aspekt, der så at sige garanterer, at hans dannelse bliver mere end blot tilpasning - sådan som Hegel sagde om den nye romantype - og det er også det, som giver romanens ulykkelige bipersoner deres vægt, hvilket mere moraliserende Goethe-fortolkninger har haft tendens til at tage for let på. I pigen Mignon - som i romanens første, upublicerede version er endnu mere kønsubestemt end i den endelige - legemliggøres en helt oprindelig opposition mod civilisationen. Hendes eksistens er en erindring om en verden før alle skel og love, før syndefaldet (ikke et ord, Goethe tager i sin mund), se f.eks. s. 147. Mignon har ikke en chance i denne verden - men romanen sætter hende et minde, som relativerer al dannelse uden alligevel at diskreditere den; skildringen af hende er hverken afvisende eller nostalgisk. Snarere kunne man sige, at såfremt Wilhelm nogen sinde skulle glemme Mignon, ville hans dannelse ende i oplysningens dialektik; så ville den mangle den skygge, som først gør den hel. Og Goethe kunne finde på at sige, at hele romanen var skrevet for Mignon-figurens skyld.

"Den skønne sjæl", hvis bekendelser udgør romanens sjette "bog”, er på sæt og vis et modstykke til Mignon: En person, som klarer sig, men på bekostning af, at "hun begrænser sin verden til et absolut minimum" (s. 150), hvad der kan være en udvej, når der ikke er andre, men det er ikke romanens morale (se s. 211 en fin formulering om, at den skønne sjæl "i sit forsøg på at gøre selvet til et fort endte med at gøre verden til et fængsel.") Hvis romanen overhovedet havde en morale, ville denne lige så vel være at finde i 
den letfærdige Philine, som griber dagen og adskilligt andet, på et tidspunkt også Wilhelm selv, der uden hende havde manglet et andet væsentligt aspekt af sin dannelse: en lykkelig erotisk oplevelse. For en sådan bliver der ikke tale om i hans sluttelige forlovelse med Natalie - eller der tales i hvert fald ikke om den. Men om Natalie nu virkelig er det ene af "to skræmmende eksempler på moderne selvundertrykkelse," (s. 212), er jeg ikke ganske sikker på.

I det hele taget - hvad Birgit Eriksson også kommenterer - har mange læsere og kritikere betragtet de sidste to "bøger" i Læreårene som en slags tour de force: "Goethe ville se at blive færdig," skrev den i sin tid berømte Emil Staiger, som forfattede tre meget læste bind om Goethe og harmoniserede ham voldsomt. Det er rigtigt, at figurerne i tårnselskabet er mindre naturalistisk tegnet end personerne i teaterverdenen, som er Wilhelms første berøring med verden; men dels skal de netop stå for andet end sig selv, dels skal man ikke overse Goethes bemærkning i et brev om, at de to sidste bøger nærmest havde skrevet sig selv, naturligvis ikke som écriture automatique, men som en konsekvens af alt det foregående, og ikke som en nødløsning, men som - løsning.

Skal man komme med indvendinger mod Birgit Eriksson, kan man begynde med den mindste: S. 119 står der, at i romanens sjette bog "bekender en ung kvinde" sin kærlighed til Jesus; men "den skønne sjæl" er på det tidspunkt, hun nedskriver sine bekendelser, faktisk en ældre kvinde, som derfor også allerede kan tale om sit forhold til følgende generationer. Vi læser ikke hendes dagbog, men hendes tilbageblik. På den følgende side (120) tales der om "en vis Stolberg", hvad der kunne tyde på, at Birgit Eriksson ikke er helt fortrolig med Goethes litteraturhistoriske kontekst (eller med den danske): Stolberg er ikke "en vis", men en temmelig kendt person, en af Goethes ungdomsvenner og mere permanent ven med bl.a. Jens Baggesen. Den af Schiller kolporterede historie om, at han skulle have brændt Goethes roman, kendes i øvrigt kun som et rygte. S. 116 mener Birgit Eriksson med støtte hos Georg Brandes, at Goethe i sin ungdom rakkede ned på det franske til fordel for det tyske; men hans artikel om domkirken i Strasbourg og dens arkitekt handlede ikke om nationale modsætninger, men om originalitet over for konvention.

I det hele taget er det nok en svaghed ved bogen, at den kun meget generelt placerer Goethe i samtiden, herunder samtidens litteratur. Det er således lidt flot blot at kalde pietismen for et "tidstypisk" fænomen (s. 121), og når der s. 186 tales om overgangen fra "den feudale storfamilie" til "den borgerlige kernefamilie" på Goethes tid, virker det letkøbt; der er løbet en del bogstaver i trykken, siden denne firkantede opfattelse var god latin. S. 168 nævner Birgit Eriksson korrekt, at Goethe bruger ordet dannelse både om naturfænomener og menneskelige forhold; men det er interessant nok den naturvidenskabelige brug (geologiske dannelser), der er den oprindelige. Det er vist heller ikke rigtigt, at Wilhelm identificerer sig "først med den syge kongesøn og så med kongen i et halvdårligt maleri” (s. 266 - han identificeres med den kongesøn, der bliver rask, dvs. maleriet fortolkes videre - som var det en roman).

Det er i orden, at Birgit Eriksson ændrer lidt i Kai Holbergs - gennemgående gode danske oversættelse og f.eks. retter "istandsætter" til "fremstiller" (s. 192). Et par steder kunne hun have rettet mere, således i Wilhelms berømte brev til vennen Werner, hvor han taler om at "danne mig selv, helt sådan som jeg er" og ikke at "danne mit selv, som det [...] er" (min kursiv, s. 200; det gør en forskel), eller "ægte og uægte" s. 236 (der står 
"falsch" og "wahr"), og "manchmal" betyder ikke "mange gange" (s. 251). Men ét sted burde hun have ladet være, nemlig når hun s. 261 citerer en person i romanen for at kritisere menneskene for at benytte kunstens mesterværker, som om de var "en blød tone". På det sted betyder det tyske "Ton" helt entydigt "ler", som Holberg skriver, og som det fremgår af, at der i næste sætning tales om skulpturkunst: Meningen er, at hvis man betragter mesterværkerne som blødt ler, som man kan modellere, som det passer en, springer man over, hvor gærdet er lavest, og lærer ikke noget, danner sig ikke.

Og endelig irriteres man over en praksis, som Birgit Eriksson ikke har fundet på og ikke skal gøres ansvarlig for, men som er og bliver en uskik: nemlig ved henvisninger kun at angive årstal på den udgave af en tekst, man har brugt. Man bør altid også anføre det originale årstal. Hvis det er længe siden, læseren sidst så noget til f.eks. Morgenstern fra 1820, kan hun eller han godt forvirres over at se ham nævnt med året 1988. Ikke mindst når man gerne vil fortælle om Goethes virkningshistorie, er det skidt at tilsløre den i stedet for at benytte originalårstal som hjælp til forståelsen.

Diskussionen med forskningen kan virke lidt tilfældig. Uden at ville tale ondt om angelsaksiske Goethe-forskere kunne man have forestillet sig en noget mere intens og eksplicit dialog med både tyske og andre, ligesom det kunne have været frugtbart ved siden af den "klassiske" Hamburger Ausgabe (der altid forkortes HA, medens det her brugte GW kan forveksles med Gesammelte Werke) at inddrage de to store nyere kommenterede udgaver, Frankfurter og Münchner. I sidstnævnte foreslår Hans-Jürgen Schings ligefrem, at man lader betegnelsen dannelsesroman hvile for en stund - vel vidende, at det næppe lader sig gøre. Men hans pointe er, at denne begrebsliggørelse kan skygge for, hvor meget i romanen, der handler om "helbredelse, livskunst, lykke" - et synspunkt, som jeg også selv i al beskedenhed har gjort gældende i forskellige sammenhænge (og så indgår, ikke at forglemme, i det tyske ord "Glück" også det, vi på dansk kalder held; og det er ikke det mindst væsentlige aspekt af det hele).

Nuvel - vi kommer ikke af med begrebet dannelsesroman og - forhåbentlig - heller ikke med begrebet dannelse. Problemet er naturligvis, at allerede betegnelsen dannelsesroman trækker fortolkerne over i retning af Schillers krav om en mere tydelig definition af, hvad det er, der foregår; altså lige præcis det, Goethe ikke kunne og ville levere. "Til syvende og sidst," sagde Goethe til Eckermann den 18. januar 1825, "synes det alt sammen ikke at ville sige andet end, at mennesket trods alle dumheder og forvirringer, ledet af en højere hånd, alligevel lykkeligt [eller heldigt!] når sit mål.” Og så skal man heller ikke tage den bemærkning for helt gode varer. Ironien er aldrig fraværende hos Goethe, så lidt som hos Thomas Mann, når han til allersidst i Josef og hans brødre, Manns egen grandiose dannelsesroman, lader Benjamin sige til Josef (der spørger, om det er virkelig sandt, hvad hans brødre siger om fader Jakobs løfte om selv som død at stå i vejen for hævnen): "Sådan særlig sandt er det sandsynligvis ikke.” I Wilhelm Meister taler teaterdirektøren Serlo om kunsten som en "opløjet/fremløjet sandhed", og nærmere kommer man ikke sagen. "Man søger et midtpunkt, og det er svært og ikke engang godt," som mesteren selv bemærkede med henblik på sin roman.

Så dér, hvor Goethe leverede, var ikke på det ideologiske, men på det stilistiske plan. I 1789, kort efter hjemkomsten fra den store rejse til Italien og med bl.a. Meister-romanen i tankerne, skrev han en opsats om "Simpel efterligning af naturen, manér, stil" forstået som en trinfølge i kunstens virkemidler. Den simple efterligning af naturen står underst, 
men er ikke desto mindre værd at beskæftige sig med for begynderen; alt begynder med den præcise iagttagelse. Manér er allerede på Goethes tid lettere nedsættende, så han forklarer, at begrebet her skal opfattes i den bedste mening: Manér er til stede, når kunstnerens subjektivitet sætter sig igennem og præger værket. Det er for så vidt et højere trin end den blotte efterligning, for naturligvis skabes kunst af en kunstner, af et individ. Men vi skal videre endnu, for det subjektives herredømme skygger stadig en smule for det sidste, som er at opnå stil. Stil er meget kort fortalt syntesen af det rent objektive (efterligning) og det rent subjektive (manér). Stil er i kunsten, hvad dannelse er i menneskelivet. Dannelse opstår jo netop heller ikke alene ved tilpasning (efterligning) eller alene ved rebellion (manér), men ved en frugtbar vekselvirkning mellem de to, i bedste fald som den syntese, der $g \varnothing$ r, at man kan tage ansvar for sig selv og helst mere end det. Og ligesom dannelse er stil et socialt ideal: Stil udvikles ikke ud af den blå luft, men gennem studium af og livtag med forgængere og store samtidige. "Mit værk er produktet af et kollektiv og har fået navnet Goethe," sagde han på sine gamle dage, hvor han også talte om "verdenslitteratur" ikke som en perlerække af mesterværker, men som en litteratur, der havde hele verden som sin forudsætning.

Paralleliteten mellem dannelse og stil hører ikke engang op ved definitionerne. Ligesom dannelse er stil noget, der kan lykkes eller mislykkes. Vel kan den ikke lykkes, uden at man gør sig umage; men selv det mest omhyggelige arbejde garanterer ikke det lykkelige udfald. Her må tilfældet, eller Vorherre, eller forsynet, eller - heldet! komme til hjælp (i en lille artikel om sin videnskabelige metode taler Goethe endda om at "vinde", som om han havde spillet $\mathrm{i}$ lotteriet eller indgået et væddemål om, at naturen vil opføre sig sådan, som han forventer). Hvad sagde ikke Adorno: De store kunstværker er dem, som på deres mest problematiske steder har heldet med sig ...

Måske burde Birgit Eriksson have genfortalt mere af romanens handling. Jeg bilder mig $i$ hvert fald ind, at læsere, der ikke er fortrolige med den - og det er jo nok de fleste - kan have svært ved at holde sammen på det, der berettes: altså holde personerne ude fra hinanden, følge med i romanens kronologi etc. (og denne omtale har næppe afhjulpet savnet). Ikke mindst gælder det de ulykkelige skæbner i romanen - Mignon, harpespilleren, Aurelie, at de bliver endnu mere til bipersoner, end de er hos Goethe, som aldrig glemmer, at Wilhelms lykkelige liv måske nok er "normen", men i virkelighedens verden undtagelsen. Endnu tydeligere bliver dette naturligvis i Wilhelm Meisters Wanderjahre, som udkom hele to gange, 1821 og i udvidet version 1829, og hvor der tales om det umulige $i$ at danne sig helt og fuldt i den moderne verden; om nødvendigheden af at gøre sig selv til "et instrument" og finde sin plads i orkestret; om industrialiseringen som et tordenvejr, der trækker op og vil lave stor ravage, og om udvandring som en mulighed for at skabe et andet og bedre liv. Hvis man for alvor vil diskutere moderne dannelse, skulle det vel egentlig snarere være ud fra vandreårene end ud fra læreårene.

Men helt overordnet har Birgit Eriksson præsteret en bog, som man er glad for at se skrevet og glad for at læse - og glad for at se på dansk i en tid, hvor det synes at være en kvalitet i sig selv at $\varnothing$ ge afstanden mellem videnskaben og den interesserede offentlighed ved at betjene sig af engelsk, selv når der ikke er nogen saglig grund til det. Bogen tager adskillige emner og delemner op, og den gør det behageligt uhysterisk: uden prætentioner om at vende alle tidligere fortolkninger på hovedet eller at fremsætte irrelevante teser 
og uden at have behov for at rakke ned på andre fortolkere for at sætte sig selv i relief. Den tager kunsten alvorligt, den tager Goethe alvorligt, og den har taget sin egen opgave alvorligt. Det er også dannelse.

Anmeldt af Per Øhrgaard

Per Øhrgaard har skrevet om Goethe i Die Genesung des Narcissus. Eine Studie zu Goethe: Wilhelm Meisters Lehrjahre (disp. 1978), Goethe. Et essay (1999) samt i diverse artikler. 